\title{
О НЕКОТОРЫХ ВОПРОСАХ АДМИНИСТРАТИВНОГО ПРЕСЛЕДОВАНИЯ ЛИЦ, ОБЛАДАЮЩИХ ОСОБЫМ ПРАВОВЫМ СТАТУСОМ, В СОВЕТСКИЙ ПЕРИОД
}

Аннотация. Предметом исследования в настоящей статье является законодательство советского периода, в котором регламентировались вопросы, связанные с особенностями привлечения к административной ответственности лии, обладающих особым правовым статусом. Объектом исследования выступают регулируемые нормами указанного законодательства общественные отношения, в которых особое место занимает деятельность прокуроров, наделявшихся полномочиями, связанными с административным преследованием лии, обладавших особым правовым статусом. Автор прослеживает эволюционные аспекты развития соответствующего законодательства, оценивает положительные и отрицательные стороны правового регулирования в рассматриваемый период. Основным методом исследования является исторический, связанный с осмыслением особенностей правового регулирования процедур административного преследования лии, обладающих особым правовым статусом. Кроме того, проводится определенный сравнительный анализ соответствующих норм и положений действующего законодательства. Основными выводом проведенного исследования является утверждение, что законодательство об особенностях привлечения к административной ответственности лии, обладающих особым правовым статусом, начало формироваться в конце 1960-хх гг. и к окончанию советского периода в 1991 г. представляло собой достаточно широкий круг норм различных законодательных актов, устанавливающих привилегированные условия, связанные с административным преследованием, для нескольких категорий указанных лиц.

Ключевые слова: административная ответственность, административное правонарушение, административное преследование, законодательство, особый правовой статус, представление прокурора, привлечение к ответственности, прокурор, согласование, судебный порядок.

Abstract. The research subject is the Soviet legislation, which had regulated the peculiarities of imposition of administrative sanctions on persons with special legal status. The research object is social relations, regulated by that legislation, with special attention to the activities of prosecutors, responsible for administrative prosecution of persons with special legal status. The author analyzes the evolutional aspects of such legislation development, assesses the positive and negative sides of legal regulation in that period. The main research method is the historical method, connected with the understanding of the peculiarities of legal regulation of the procedures of administrative prosecution of persons with special legal status. Besides, the author compares the corresponding norms and provisions of the current legislation. The author concludes that the legislation, regulating the peculiarities of imposition of administrative sanctions on the persons with special legal status, started forming in the late 1960s, and by the end of the Soviet period in 1991 it had contained a wide range of legislative provisions, guaranteeing special conditions of administrative prosecution of several categories of persons with special legal status.

Key words: petition by a public prosecutor, special legal status, legislation, administrative prosecution, administrative offence, administrative responsibility, imposition of sanctions, prosecutor, agreement, court order.

$\mathrm{B}$ отечественной науке административного права до настоящего времени не получили должного внимания вопросы, связанные с развитием предусмотренного ч. 2 ст. 1.4 Кодекса Российской Федерации об административных правонарушениях института привлечения к административной ответственности должностных лиц, выполняющих определенные государственные функции, что под- тверждается достаточно малым количеством публикаций в научных журналах по этой проблематике. Помимо автора настоящей статьи [1] этому вопросу посвящали свои краткие исследования И. Алешина [2], В.3. Гущин [3], Н.М. Жданов [4], С.П. Казанков [5], И.П. Сергеев [6] и ряд других ученых и практиков. Большинство изученных нами комментариев к названному кодифицированному акту от- 
личаются завидной лаконичностью в этом вопросе, что лишний раз подчеркивает тезис о необходимости более глубоких исследований рассматриваемого правового института. Как представляется, одним из направлений исследования является анализ генезиса обозначенной правовой проблемы, корни которой уходят еще в советский докодификационный период, когда начали формироваться основы современных законодательных подходов к наделению определенными иммунитетными гарантиями отдельных лиц, обладающих особым правовым статусом. Это собирательное понятие для таких субъектов правоотношений мы обозначили в ранее опубликованной статье, посвященной в большей степени роли прокуроров в административном преследовании соответствующих субъектов [7], поскольку иная нормативно закрепленная терминология объединяющего назначения до 2002 г. в принципе отсутствовала. С учетом уже затронутых вопросов в указанной статье, к которой адресуем читателя, попытаемся дать характеристику особенностям правового регулирования института привлечения к административной ответственности лиц, обладающих особым правовым статусом, в советский период.

Первые законодательные новации по этому вопросу пришлись на конец 1960-х - начало 1970х гг., когда на уровне РСФСР были приняты соответственно законы от 19.07.1968 «О поселковом, сельском Совете народных депутатов РСФСР» [8], от 29.07.1971 «0 районном Совете народных депутатов РСФСР» [9] и «О городском, районном в городе Совете народных депутатов РСФСР» [10], где предусматривалось обязательное согласование Советами (в период между сессиями - исполкомами Советов) применения к депутатам соответствующего уровня мер административного взыскания, а также последующее возможное обращение прокуроров в вышестоящие Советы в случае принятия «неправильного» решения.

Чуть позже в процесс правового регулирования включился федеральный законодатель. Так, Законом СССР от 20.09.1972 «О статусе народных депутатов в СССР»[11] в ст. 33 было предусмотрено, депутат Верховного Совета СССР и депутат Верховного Совета союзной республики не могли быть подвергнуты мерам административного взыскания, налагаемым в судебном порядке, без согласия соответственно Верховного Совета СССР, Верховного Совета союзной республики, а в период между их сессиями - без согласия Президиума Верховного Совета. В свою очередь депутат Верховного Совета автономной республики на территории автономной республики, а также на всей территории союзной республики, в которой состояла автономная республика, не мог быть подвергнут мерам административного взыскания, налагаемым в судебном порядке, без согласия Верховного Совета автономной республики, а в период между его сессиями - без согласия Президиума Верховного Совета автономной республики. Как видим, в первом случае законодателем не устанавливались территориальные ограничения для применения особого порядка, хотя в ситуации с депутатами республиканского уровня это, по нашему мнению, являлось избыточной гарантией.

Статьей 34 рассматриваемого союзного законодательного акта устанавливалось, что депутат краевого, областного Совета, Совета автономной области, автономного округа, районного, городского, районного в городе, поселкового, сельского Совета народных депутатов не мог быть на территории соответствующего Совета подвергнут мерам административного взыскания, налагаемым в судебном порядке, без согласия соответствующего Совета, а в период между сессиями - без согласия его исполнительного комитета. Эта норма в отличие от предыдущей предусматривала оспаривание прокурором в вышестоящий совет принятого решения.

Во второй половине 1970-х гг. вопросы, связанные с определением особого статуса депутатов в административно-юрисдикционной сфере, нашли свое закрепление в актах конституционного права. Так, в соответствии со ст. 123 (с 1988 г. - ст. 124, с 1990 г. - снова ст. 123) Конституции (Основного Закона) Союза Советских Социалистических Республик [12], принятой Верховным Советом СССР 07.10.1977, народный депутат СССР не мог быть подвергнут мерам административного наказания, налагаемым в судебном порядке, без согласия Верховного Совета СССР, а в период между его сессиями без согласия Президиума Верховного Совета СССР. Аналогичный подход, но уже в отношении депутатов Верховного Совета РСФСР был применен в ст. 112 Конституции (Основного Закона) РСФСР [13], принятой Верховным Советом РСФСР 12.04.1978, где согласующими органами выступали соответственно Верховный Совет РСФСР и Президиум Верховного Совета РСФСР (в связи с внесенными в конце 1991 г. изменениями согласование применения в отношении народного депутата Российской Федерации мер административного взыскания было возложено соответственно на Съезд народных депутатов РФ и Верховный Совет РФ).

В конце 1970-х гг. также был расширен круг субъектов, на которых распространялся особый порядок административного преследования. Так, в силу ст. 50 Закона СССР от 06.07.1978 № 7772-IX «0 выборах в Верховный Совет СССР» [14] согласие в отношении кандидата в депутаты Верховного Совета СССР был уполномочен давать Прези- 


\section{Административное и муниципальное право 10 (106) 2016}

диум Верховного Совета СССР, сообщая об этом в случае положительного решения в Центральную избирательную комиссию (СССР) и в соответствующую окружную избирательную комиссию. Аналогичный подход был применен и в ст. 47 Закона РСФСР от 08.08.1978 «0 выборах в Верховный Совет РСФСР» [15] в отношении кандидатов в депутаты Верховного Совета РСФСР, где согласующий орган - Президиум Верховного Совета РСФСР в случае положительного решения обязан был сообщить об этом в Центральную избирательную комиссию (РСФСР) и соответствующую окружную избирательную комиссию.

Статьей 11 Закона СССР от 30.11.1979 «О Верховном Суде СССР» [16] круг лиц, обладающим особым правовым статусом, был дополнен судьями Верховного Суда СССР и народными заседателями Верховного Суда СССР (с оговоркой «при осуществлении правосудия»), согласие на применение мер административного взыскания в отношении которых принимал Верховный Совет СССР, а в период между сессиями - Президиум Верховного Совета СССР. В свою очередь Законом СССР от 25.06.1980 № 2370-Х «0 внесении изменений и дополнений в Основы законодательства о судоустройстве Союза ССР, союзных и автономных республик» [17] были в новой редакции утверждены Основы, согласно ст. 36 которых судьи, а также народные заседатели «при исполнении ими обязанностей в суде» (обращает на себя внимание некоторое расхождение этой оговорки с примененной в Законе СССР «О Верховном Суде СССР» формулировкой «при осуществлении правосудия») не могли быть подвергнуты мерам административного взыскания, налагаемым в судебном порядке:

1) народные судьи и народные заседатели народных судов, председатели, заместители председателей, члены и народные заседатели краевых, областных, городских судов, судов автономных областей и автономных округов и Верховных Судов автономных республик -- без согласия Президиума Верховного Совета союзной республики;

2) председатели, заместители председателей и члены Верховных Судов союзных республик, а также народные заседатели этих судов - без согласия Верховного Совета союзной республики, а в период между сессиями - Президиума Верховного Совета союзной республики;

3) председатели, заместители председателей, члены и народные заседатели военных трибуналов - без согласия Президиума Верховного Совета СССР;

4) Председатель, заместители Председателя и члены Верховного Суда СССР, а также народные заседатели Верховного Суда СССР - без согласия Верховного Совета СССР, а в период между сессиями - Президиума Верховного Совета СССР.

Как видим, что, как и в случаях с депутатами и кандидатами в депутаты различного уровня, в отношении судей была установлена четкая компетенция согласующих принятие решения органов. При этом сохранялась общая тенденция наделения правом дачи согласия исключительно представительных органов власти.

Принятые Верховным Советом СССР 23.10.1980 Основы законодательства Союза ССР и союзных республик об административных правонарушениях [18], действие которых на территории России официально было прекращено лишь с 1 июля 2002 г., не содержали положений, выделяющих отдельные категории лиц (либо допускающих наличие таковых), подлежащих административной ответственности в особом порядке, что можно отнести к недостаткам этого кодифицированного акта. Впрочем, данное обстоятельство едва ли можно рассматривать как отрицание легального характера перечисленных выше, а также нижеприводимых норм других законодательных актов. В свою очередь и принятый Верховным Советом РСФСР 20.06.1984 Кодекс РСФСР об административных правонарушениях [19], который также применялся до 1 июля 2002 г., ни в первоначальной, ни в последующих редакциях не содержал каких-либо пояснений по рассматриваемому вопросу.

Последние годы советского периода ознаменовались принятием новых законодательных актов, в том числе пришедших на смену выше упомянутым, в которых оговаривался особый порядок применения мер административного взыскания.

Так, в соответствии со ст. 50 [18] кандидат в народные депутаты СССР не мог быть подвергнут мерам административного взыскания, налагаемым в судебном порядке, без согласия Центральной избирательной комиссии. Немного позже ст. 43 Закона РСФСР от 27.10.1989 «0 выборах народных депутатов РСФСР» [20] аналогичного рода привилегия была распространена на кандидатов в народные депутаты РСФСР, причем законодатель не оговаривал ее применение исключительно территорией РСФСР, что, возможно, считалось само собой разумеющимся. В качестве согласующего административное преследование органа называлась республиканская Центральная избирательная комиссия. В свою очередь в силу ст. 45 Закона РСФСР от 27.10.1989 «0 выборах народных депутатов местных Советов народных депутатов РСФСР» [22] кандидат в народные депутаты местного Совета народных депутатов не подлежал мерам административного взыскания, налагаемым в судебном порядке, без согласия соответствующей краевой, 
областной, автономной области, окружной (автономного округа), районной, городской, районной в городе, поселковой, сельской избирательной комиссии. Как видим, и здесь законодатель не посчитал нужным закрепить территориальную привязку к месту совершения административного проступка, что можно рассматривать как явный недостаток нормы.

Определенную новизну в механизм привлечения к административной ответственности внес п. 4 ст. 6 Закона СССР от 04.08.1989 «0 статусе судей в СССР» [23], согласно которому не допускалось применение мер административного взыскания в отношении судьи, а также народного заседателя при исполнении ими обязанностей в суде. То есть данная норма фактически снимала с повестки дня вопрос о привлечении к административной ответственности указанных в ней лиц за совершение правонарушений в рамках осуществления функции правосудия.

Закон СССР от 21.12.1989 «0 статусе народных депутатов в СССР» [24], сохранив основные тенденции в отношении отдельных категорий депутатов и дающих согласие на привлечение их к административной ответственности представительных органов власти, закрепленные в ранее действовавшем одноименном законодательном акте [25], тем не менее детализировал в ст. 39 порядок получения согласия Совета на привлечение депутата к административной ответственности, где законодатель впервые наделил прокуроров правом самостоятельно обращаться с представлением о снятии неприкосновенности с депутатов местных Советов, что, по нашему мнению, создало основу для формирования соответствующей современной правовой базы.

В статье 35 Закона СССР от 31.05.1990«0 статусе народного депутата СССР» [26] был закреплен алгоритм исполнения гарантированных ст. 123 Конституции (Основного Закона) СССР требований к особому порядку привлечения народного депутата СССР к административной ответственности, согласно которому для получения согласия Верховного Совета СССР, а в период между сессиями - Президиума Верховного Совета СССР на применение мер административного взыскания, налагаемых в судебном порядке, Генеральный прокурор СССР перед направлением дела об административном правонарушении в суд обязан был внести в Верховный Совет СССР представление.

Еще одним шагом, закрепляющим непосредственное участие прокуроров в административном преследовании, стал Закон РСФСР от 30.10.1990 «0 статусе народного депутата местного Совета народных депутатов РСФСР» [27], в соответствии со ст. 30 которого народный депутат на территории соответствующего Совета не мог быть подвергнут мерам административного взыскания, налагаемым в судебном порядке, без согласия соответствующего Совета. При этом производство по делу об административном правонарушении в отношении народного депутата могло быть возбуждено только прокурором соответствующего уровня или вышестоящим прокурором с согласия Совета.

Усиливающим роль прокуроров и реализующим в свою очередь положения ст. 112 Конституции (Основного Закона) РСФСР правовым актом являлся Закон РСФСР от 15.11.1990 «О статусе народного депутата РСФСР» [28], статья 31 которого установила, что производство до делу об административном правонарушении, ответственность за которое налагается в судебном порядке, в отношении народного депутата РСФСР могло быть возбуждено только Прокурором РСФСР с согласия Съезда народных депутатов РСФСР или Верховного Совета РСФСР.

Закон РСФСР от 24.04.1991 № 1096-1 «0 Выборах Президента РСФСР» [29] закрепил новую категорию лиц, обладающим особым правовым статусом, - кандидатов в Президенты РСФСР, которые в соответствии со ст. 9 не могли быть подвергнуты административному взысканию, налагаемому в судебном порядке, без согласия Центральной избирательной комиссии по выборам Президента РСФСР.

Появление еще одной категории лиц, преследуемых за совершение административных проступков в особом порядке, связано с зарождением в последние годы советского периода конституционного судопроизводства. Так, статья 27 Закона СССР от 23.12.1989 «О конституционном надзоре в СССР» [30] устанавливала, что лицо, избранное в Комитет конституционного надзора СССР, не может быть подвергнуто мерам административного взыскания, налагаемым в судебном порядке, без согласия Комитета. Решение о согласии принималось тайным голосованием двумя третями голосов состава Комитета конституционного надзора СССР. Недостатком этой нормы являлось отсутствие указания на лиц, имеющих право выходить в данный Комитет с соответствующим представлением.

В свою очередь в ст. 17 Закона РСФСР от 06.05.1991 «О Конституционном Суде РСФСР» [31] было закреплено, что:

- судья Конституционного Суда РСФСР не может быть подвергнут мерам административного взыскания, кроме штрафа, взыскиваемого на месте совершения административного правонарушения, без согласия Конституционного Суда РСФСР;

- производство по делу об административном правонарушении в отношении судьи Конституционного Суда РСФСР могло быть возбуждено только Генеральным прокурором РСФСР; 


\section{Административное и муниципальное право 10 (106) 2016}

- судья Конституционного Суда РСФСР, задержанный или доставленный в орган внутренних дел в порядке производства по делам об административных правонарушениях, должен быть освобожден немедленно по выяснении его личности.

Рассмотренный законодательный акт привнес сразу несколько новых подходов к применению особого порядка, а именно:

- $\quad$ появился еще один согласующий орган - Конституционный Суд РСФСР;

- допускалось применение в отношении судьи наказания в виде административного штрафа без необходимости согласования этого с Конституционным Судом РСФСР;

- исключительным правом инициирования административного преследования в отношении судьи Конституционного Суда РСФСР обладал Генеральный прокурор РСФСР;

- задержание и доставление судьи не запрещалось, но он подлежал освобождению после выяснения его личности.

Согласно ст. 24 Закона РСФСР от 04.07.1991 № 1543-1 «Об арбитражном суде» [32], действовавшего до 1995 г., судья арбитражного суда не мог быть подвергнут мерам административного взыскания, налагаемым в судебном порядке, без согласия соответственно Верховного Совета РСФСР, Верховного Совета республики в составе РСФСР, а в период между сессиями - их Президиумов либо без согласия Совета народных депутатов автономной области, автономного округа. При этом судья арбитражного суда, задержанный или доставленный в орган внутренних дел в порядке производства по делам об административных правонарушениях, подлежал освобождению немедленно по выяснении его личности. Дело об административном правонарушении в отношении судьи арбитражного суда могло быть возбуждено только соответственно Генеральным прокурором РСФСР, прокурором республики в составе РСФСР, прокурором автономной области, автономного округа.

Закон РСФСР от 24.10.1991 № 1803-1 «0 выборах главы администрации» [33] в ст. 26 содержал запрет на применение административного взыскания, налагаемого в судебном порядке, в отношении кандидата на должность главы администрации без согласия окружной избирательной комиссии. Это был последний законодательный акт, принятый в рассматриваемый период, но продолжавший действовать в 1990-е гг. уже в новом государстве Российской Федерации. При этом лица, имевшие право возбуждать производство по делу, а равно обращаться за согласием на привлечение указанного кандидата к административной ответственности, законодателем не оговаривались.
Таким образом, подводя итог проведенному анализу законодательства советского периода, отметим следующее:

1) выделение в законодательстве лиц, обладающих особым правовым статусом в части привлечения к административной ответственности, началось в конце 1960-х гг. с депутатов местных Советов;

2) появление прокурора как участника применения особых процедур в отношении депутатов местных Советов произошло также в конце 1960-х гг. и это участие от первоначального оспаривания решений местных Советов трансформировалось сначала в самостоятельное обращение в такие Советы за получением согласия на привлечение депутата к административной ответственности, а затем и в исключительное право прокурора возбуждать производства по делам об административных правонарушениях в отношении представителей депутатского корпуса;

3) гарантии неприкосновенности депутатов в части применения особого порядка привлечения их к административной ответственности были закреплены в конституциях СССР и РСФСР в конце 1970-х гг;

4) перечень отдельных категорий лиц в конце 1970-х гг. был расширен за счет кандидатов в депутаты Верховных Советов СССР и РСФСР, а также судей Верховного Суда СССР и народных заседателей Верховного Суда СССР;

5) принятые в первой половине 1980-х гг. союзный и российский законодательные акты об административных правонарушениях не содержали каких-либо указаний в отношении отдельных категорий лиц, обладающих особым правовым статусом;

6) в рамках совершенствования законодательства о выборах в конце 1980-х гг. в качестве органов, согласующих привлечение к административной ответственности кандидатов в депутаты, были определены новые структуры - избирательные комиссии соответствующего уровня;

7) в конце 1980-х - начале 1990-х гг. перечень отдельных категорий лиц пополнился членами Комитета конституционного надзора СССР и судьями Конституционного Суда РСФСР, согласование административного преследования в отношении которых было отнесено к ведению данных органов, а также судьями вновь созданных арбитражных судов, кандидатами в Президенты РСФСР и на должность главы администрации;

8) как правило, особый порядок устанавливался для применения мер административного взыскания, налагаемых в судебном порядке, однако встречались и исключения из общих правил. 
Библиография:

1. Винокуров А.Ю. Участие прокурора в административном преследовании должностных лиц, выполняющих определенные государственные функции // Административное и муниципальное право. - 2013. - № 1. - С. 30-35.

2. Алешина И. Привлечение судей к административной, дисциплинарной и уголовной ответственности // Законность. - 2005. - № 6. - с. 89.

3. Гущин В.3. Особенности привлечения к административной ответственности членов Совета Федерации, депутатов Государственной Думы и особенности президентского иммунитета от привлечения к административной ответственности // Современное право. - 2013. - № 8. - С. 21-23.

4. Жданов Н.М. Об административной ответственности должностных лиц, выполняющих определенные государственные функции // Административ-ное право и процесс. - 2013. - № 9. - С. 33-37.

5. Казанков С.П. Конституционно-правовые гарантии при привлечении к уголовной и административной ответственности депутатов Государствен-ной Думы и членов Совета Федерации // Государственная власть и местное самоуправление. - 2010. - № 6. - С. 33-35.

6. Сергеев И.П. Административная ответственность судей // Российский судья. - 2005. - № 9. - С. 76.

7. Винокуров А.Ю. Участие прокурора в административном преследовании лиц, обладающих особым правовым статусом, в советский период // Административное и муниципальное право. - 2016. - № 9. - С. 32.

8. Свод законов РСФСР. - 1988. - Т. 1. - С. 763.

9. Ведомости Верховного Совета РСФСР. - 1971. - № 31. - Ст. 653.

10. Ведомости Верховного Совета РСФСР. - 1971. - № 31. - Ст. 654 (с посл. изм.).

11. Ведомости Верховного Совета СССР. - 1972. - № 39. - Ст. 347 (с посл. изм.).

12. Ведомости Верховного Совета СССР. - 1977. - № 41. - Ст. 617 (с посл. изм.).

13. Ведомости Верховного Совета РСФСР. - 1978. - № 15. - Ст. 407 (с посл. изм.)

14. Ведомости Верховного Совета СССР. - 1978. - № 28. - Ст. 441.

15. Ведомости Верховного Совета РСФСР. - 1978. - № 32. - Ст. 845 (с посл. изм.).

16. Ведомости Верховного Совета СССР. - 1979. - № 49. - Ст. 842.

17. Ведомости Верховного Совета СССР. - 1980. - № 27. - Ст. 545.

18. Ведомости Верховного Совета СССР. - 1980. - № 44. - Ст. 909.

19. Ведомости Верховного Совета РСФСР. - 1984. - № 27. - Ст. 909 (с посл. изм.).

20. Ведомости Верховного Совета СССР. - 1988. - № 49. - Ст. 729.

21. Ведомости Верховного Совета РСФСР. - 1989. - № 44. - Ст. 1305.

22. Ведомости Верховного Совета РСФСР. - 1989. - № 44. - Ст. 1306.

23. Ведомости СНД СССР и ВС СССР. - 1989. - № 9. - Ст. 223.

24. Ведомости СНД СССР и ВС СССР. - 1989. - № 29. - Ст. 567.

25. Закон СССР от 20.09.1972 «О статусе народных депутатов в СССР».

26. Ведомости СНД СССР и ВС СССР. - 1990. - № 24. - Ст. 443.

27. Ведомости СНД РСФСР и ВС РСФСР. - 1990. - № 23. - Ст. 279.

28. Ведомости СНД РСФСР и ВС РСФСР. - 1990. - № 25. - Ст. 312.

29. Ведомости СНД РСФСР и ВС РСФСР. - 1991. - № 17. - Ст. 510.

30. Ведомости СНД СССР и ВС СССР. - 1989. - № 29. - Ст. 572.

31. Ведомости СНД РСФСР и ВС РСФСР. - 1991. - № 19. - Ст. 621.

32. Ведомости СНД РСФСР и ВС РСФСР. - 1991. - № 30. - Ст. 1013 (с посл. изм.).

33. Ведомости СНД РСФСР и ВС РСФСР. - 1991. - № 45. - Ст. 1491 (с посл. изм.).

\section{References (transliterated):}

1. Vinokurov A.Yu. Uchastie prokurora $\mathrm{v}$ administrativnom presledovanii dolzhnostnykh lits, vypolnyayushchikh opredelennye gosudarstvennye funktsii // Administrativnoe i munitsipal'noe pravo. - 2013. - № 1. - S. 30-35.

2. Aleshina I. Privlechenie sudei k administrativnoi, distsiplinarnoi i ugolovnoi otvetstvennosti // Zakonnost'. - 2005. - № 6. - s. 89.

3. Gushchin V.Z. Osobennosti privlecheniya k administrativnoi otvetstvennosti chlenov Soveta Federatsii, deputatov Gosudarstvennoi Dumy i osobennosti prezidentskogo immuniteta ot privlecheniya k administrativnoi otvetstvennosti // Sovremennoe pravo. - 2013. - № 8. - S. 21-23.

4. Zhdanov N.M. Ob administrativnoi otvetstvennosti dolzhnostnykh lits, vypolnyayushchikh opredelennye gosudarstvennye funktsii // Administrativ-noe pravo i protsess. - 2013. - № 9. - S. 33-37.

5. Kazankov S.P. Konstitutsionno-pravovye garantii pri privlechenii k ugolovnoi i administrativnoi otvetstvennosti deputatov Gosudarstven-noi Dumy i chlenov Soveta Federatsii // Gosudarstvennaya vlast' i mestnoe samoupravlenie. - 2010. - № 6. - S. 33-35.

6. Sergeev I.P. Administrativnaya otvetstvennost' sudei // Rossiiskii sud'ya. - 2005. - № 9. - S. 76.

7. Vinokurov A.Yu. Uchastie prokurora v administrativnom presledovanii lits, obladayushchikh osobym pravovym statusom, v sovetskii period // Administrativnoe i munitsipal'noe pravo. - 2016. - № 9. - S. 32.

8. Svod zakonov RSFSR. - 1988. - T. 1. - S. 763.

9. Vedomosti Verkhovnogo Soveta RSFSR. - 1971. - № 31. - St. 653.

10. Vedomosti Verkhovnogo Soveta RSFSR. - 1971. - № 31. - St. 654 (s posl. izm.). 


\section{Административное и муниципальное право 10 (106) 2016}

11. Vedomosti Verkhovnogo Soveta SSSR. - 1972. - № 39. - St. 347 (s posl. izm.).

12. Vedomosti Verkhovnogo Soveta SSSR. - 1977. - № 41. - St. 617 (s posl. izm.).

13. Vedomosti Verkhovnogo Soveta RSFSR. - 1978. - № 15. - St. 407 (s posl. izm.)

14. Vedomosti Verkhovnogo Soveta SSSR. - 1978. - № 28. - St. 441.

15. Vedomosti Verkhovnogo Soveta RSFSR. - 1978. - № 32. - St. 845 (s posl. izm.).

16. Vedomosti Verkhovnogo Soveta SSSR. - 1979. - № 49. - St. 842.

17. Vedomosti Verkhovnogo Soveta SSSR. - 1980. - № 27. - St. 545.

18. Vedomosti Verkhovnogo Soveta SSSR. - 1980. - № 44. - St. 909.

19. Vedomosti Verkhovnogo Soveta RSFSR. - 1984. - № 27. - St. 909 (s posl. izm.).

20. Vedomosti Verkhovnogo Soveta SSSR. - 1988. - № 49. - St. 729.

21. Vedomosti Verkhovnogo Soveta RSFSR. - 1989. - № 44. - St. 1305.

22. Vedomosti Verkhovnogo Soveta RSFSR. - 1989. - № 44. - St. 1306.

23. Vedomosti SND SSSR i VS SSSR. - 1989. - № 9. - St. 223.

24. Vedomosti SND SSSR i VS SSSR. - 1989. - № 29. - St. 567.

25. Zakon SSSR ot 20.09.1972 «0 statuse narodnykh deputatov v SSSR».

26. Vedomosti SND SSSR i VS SSSR. - 1990. - № 24. - St. 443.

27. Vedomosti SND RSFSR i VS RSFSR. - 1990. - № 23. - St. 279.

28. Vedomosti SND RSFSR i VS RSFSR. - 1990. - № 25. - St. 312.

29. Vedomosti SND RSFSR i VS RSFSR. - 1991. - № 17. - St. 510.

30. Vedomosti SND SSSR i VS SSSR. - 1989. - № 29. - St. 572.

31. Vedomosti SND RSFSR i VS RSFSR. - 1991. - № 19. - St. 621.

32. Vedomosti SND RSFSR i VS RSFSR. - 1991. - № 30. - St. 1013 (s posl. izm.).

33. Vedomosti SND RSFSR i VS RSFSR. - 1991. - № 45. - St. 1491 (s posl. izm.). 